\title{
EGOVERNMENT AS AN ELEMENT OF THE RIGHT TO GOOD ADMINISTRATION
}

\author{
Justyna Matusiak ${ }^{1}$ and Marcin Princ ${ }^{2}$
}

DOI: 10.24989/ocg.v331.3

\begin{abstract}
The right to good administration constitutes an established principle of European Union law, which includes the procedural rights of stakeholders in administrative proceedings, the result of which may affect their interests. Article 41 of the European Union Charter of Fundamental Rights states that every person has the right to have his or her affairs handled impartially, fairly and within a reasonable time by the institutions and bodies of the Union. When it comes to reasonable time of handling the case one can ask if eGovernment solutions are the guarantee of such a right.
\end{abstract}

eGovernment understood as the use of all kinds of electronic means of communication, in particular, however, the Internet, improves services provided by the state to its citizens. The usage of IT technology in public administration allows it to perform its activities in a more efficient way. This improvement applies not only to the communication between parties but also to the quality of citizens' life.

To sum up, one can ask the question if the European right to good administration can be understood as the right to eGovernment solutions and if so, to what extent. Which services and technical solutions should be guaranteed as ones ensuring challenges of good administration?

\section{Introduction}

The right to good administration, as well as eGovernment are two separate challenges facing current public administration. This means that, on one hand, administration must meet current standards of, so called, good administration, and on the other, it must meet contemporary requirements of the information society.

The purpose of this paper is to answer the question whether there is any relationship between the above topics. The research problem of this study comprises mainly issues of European administrative law. The study presents fundamental themes of defining the right to good administration and the concept of eGovernment. Furthermore, the study shows examples of the implementation of law for good administration, with special attention to eGovernment solutions.

The implementation of the aforementioned law requires financial spending from the centralgovernment budget. Current public administration that meets ICT standards is not cheap. The struggle for funds from central-government budget is increasing in intensity, since there is a steady increase of spending at the level of social, health, and educational requirements. How to justify

\footnotetext{
${ }^{1}$ WSB University in Poznań, Institute of Law and Administration, Powstańców Wielkopolskich 5, 61-895 Poznań, Poland, justyna.matusiak@wsb.poznan.pl, http://www.wsb.pl/english/.

${ }^{2}$ Adam Mickiewicz University in Poznań, Faculty of Law and Administration, al. Niepodległości 53, 61-714 Poznań, Poland, m.princ@amu.edu.pl, https://prawo.amu.edu.pl/en.
} 
additional expenditure on eAdministration? One justification may be the fact that eGovernment is an element of the right to good administration.

\section{Defining the right to good administration}

The 20th century brought about a number of changes in the perception of existing relations and institutions. One good example in that respect is the legal construction of citizenship, which changed the relationship between the state and the individual. Citizens, apart from the obligations imposed on them, gained a lot of rights under the agreement which ties them to the state.

The establishment of right to good administration is the result of the development of society. This is also stressed by I. Lipowicz [1], the Ombudsman in Poland in the years 2010-2015, who states, that the existence of the right to good administration comes from an increased citizenship awareness. It is appropriate to support the claim that the administered no longer wanted to sit back and merely watch what is happening in public administration, but rather want to have their say in pursuing the ideal [2].

The subject of good administration resurfaced with the creation of the Charter of Fundamental Rights of the European Union [3] and the European Code of Good Administrative Behavior. The right to good administration is set out in Article 41 of the Charter. It stipulates that "Every person has the right to have his or her affairs handled impartially, fairly and within a reasonable time by the institutions, bodies, offices and agencies of the Union. Additionally, the Charter guarantees "the right of every person to be heard, before any individual measure which would affect him or her adversely is taken", "the right of every person to have access to his or her file, while respecting the legitimate interests of confidentiality and of professional and business secrecy" and "the obligation of the administration to give reasons for its decisions". In addition, it is stipulated that: "Every person has the right to have the Union make good any damage caused by its institutions or by its servants in the performance of their duties, in accordance with the general principles common to the laws of the Member States" and that: "Every person may write to the institutions of the Union in one of the languages of the Treaties and must have an answer in the same language".

It should be stressed that the provisions of the Charter were incorporated in the Treaty provisions. Within the meaning of Article 6.1 of the Treaty of Lisbon amending the Treaty of the European Union and the Treaty Establishing the European Community [4] and signed in Lisbon on 13 December 2007, the Union recognizes the rights, freedoms, and principles set out in the Charter of Fundamental Rights of the European Union of 7 December 2000, in the wording finalized on 12 December 2007 in Strasbourg.

The wording of Article 41 of the Charter is a compromise of sorts. The current understanding of the requirements of good administration is undoubtedly also under the influence of the provisions of the European Code of Good Administrative Behavior (European Code of Good Administrative Practice), recommendation R (2007) 7 of the Committee of Ministers of Member States concerning good administration, or the drafted European Union Code of Conduct [5, 6, 7]. Among the provisions set out in the aforementioned legal acts there are, inter alia, the following rules which are part of the current understanding of good administration: rule of law, equality, impartiality, proportionality, legal certainty, undertaking actions at the right time, participation, respect for privacy, principle of coherence and reasonable expectations, transparency, principle of efficiency and utility, and the principle of honesty. 
The right to good administration is interpreted in different ways. According to Z. Cieślak [8], it can be understood as:

1) the right of a citizen, who by interacting with administration, is entitled to demand that the right to good administration be exercised,

2) public subjective right shaped by legal procedures and institutions which are to implement the demand for exercising good administration,

3) pseudo-legal category - understood as a non-binding legal rule resulting from and summarizing the legal system,

4) non-legal category - understood as a social phenomenon deriving from political relations, social aspects, based on ethical assessments.

Presently, one should fully agree with I. Lipowicz's [9] opinion, that the adoption of the Charter of Fundamental Rights of the European Union transferred the right of good administration from the non- and pseudo-legal categories to the set of "civil rights" of EU citizens. This right is usually defined as a set of procedural subjective rights $[10,11]$, sometimes, with its individual elements, classified within the framework of procedural dignity [12]. Following the European legislator who placed it in the fundamental legal act, i.e. in the Charter of Fundamental Rights of the EU, we should suppose that we are dealing with a fundamental right [13], which still has an unclear status of an "umbrella-right" [14]. At the same time, it should be noted that some legal theorists place the right to good administration in the category of, so called, third generation rights [15]. Sometimes, however, it is claimed that this right cannot be considered in the category of human rights stemming from the innate and nontransferable dignity of the human being, but rather they should be associated with the construction of a democratic rule of law [16].

The right to good administration is a European standard [17]. At the same time, equally valid is the opinion expressed by W. Chróścielewski and Z. Kmieciak [18], who claim that the right to good administration at present can be associated with a set of legal standards referring to public administration activities so cohesive, unambiguous and precise that they can be treated as evaluation criteria for assessing the correctness of different solutions existing within the national legal order. In the implementation of standards the national legislator is free to select the means of such implementation [19].

It seems safe to say, that on the basis of the classic three-branch separation of powers, with respect to the legislative power of the highest importance are the principles of decent legislation, with respect to the judicial power - the principle of fair procedure and the right to a fair trial, consequently, with respect to the executive power, public administration in particular, the right to and principle of good administration.

\section{3. eGovernment - computerization of public entities}

The legal basis for the existence of good practices in administrative bodies can be derived from different regulations related to administrative law, including also in areas where the process of computerization of public authorities is prominently visible [20]. 
The definition of eGovernment evolved over time, and in literature one can find different approaches to its definition, as analyzed, e.g. by R. Gil-Garcia [21]. For the purposes of this study one can adopt the definition proposed by the Author who points that electronic government is a selection, design, implementation, and use of information and communication technologies in government to provide public services, improve managerial effectiveness, and promote democratic values and participation mechanisms, as well as the development of a legal and regulatory framework that facilities information intensive initiatives and fosters the knowledge society. In other words, eGovernment refers to the use of information and communication technology tools and applications to enhance government transparency and accountability in public administration by improving public services delivery, access to information and services and public governance [22]. Public governance, which is a concept which can be understood more broadly than eGovernment, is a process of managing a complex society with the participation of entities from the public and private sectors, often in the form of a network, in which the central place does not have to belong to public administrative authorities [23].

The element which appears in most eGovernment-related definitions is effectiveness (consequently, also a resolution of a matter within a reasonable time), and democratic principles (specifically, impartiality and fairness). In literature $[24,25]$ there are many studies which point whether and how these goals have been achieved. S. Bhatnagar [26] gives specific examples of saving time after the introduction of eGovernment solutions in such places as Brazil, Chile, China, India, Jamaica, the Philippines, or Singapore. Although the implementation of eGovernment related projects still faces many problems, in many countries, including Poland, the Czech Republic, or Germany, the question is being asked whether it counts from the point of view of good administration. It has to be underlined that failures, which vary from not establishing project success to missing citizen expectations and adoption, even to preferences in turning back to traditional channel section (i.e. face-to-face visits and voice phone calls) cause the questioning of both eGovernment feasibility and sustainability [27].

Electronic government (eGovernment) comprises electronic administration (eAdministration), i.e. electronic services provided to natural persons and businesses provided by public entities, and electronic democracy (eDemocracy), i.e. citizens' active participation in political life to improve their quality of life. eAdministration, which uses modern tools provided by information and communication technologies, is often pointed to as the key initiator and performer of the changes which are taking place [28]. Thanks to some unchanging attributes, public administration can use IT techniques in such a way, so as to perform its activities in the most efficient manner.

eAdministration is not the contradiction of the ideal bureaucratic structure formulated by Max Weber. Although eAdministration is described [29] as non-bureaucratic, transparent, effective, cheap, and fast, i.e. efficient and friendly, this is not exactly the truth. The handling of cases in a bureaucratic way simply means that they are managed in accordance with the rules of a bureaucratic organization, which organization is the materialization of the concept of the rule of law. Consequently, one can postulate [30] that attempts are being made to reform the bureaucratic organization of public administration, and use new technologies to implement this reform. Literature states [31] that the Weberian model is such a form of organization which in the nearest future, at least over the next few decades, will still be in place. If a new type of the organizational form is to appear, then it is hard to specify how it will look like. Therefore, it is said, that presently one can only talk about bureaucracy being under the influence of information technologies, about information-based bureaucracy. Such position expressed in literature [32], is connected with another concept, namely eBureaucracy. Authors state that eBureaucracies are organizations that 
follow the procedural logic of a public bureaucracy, to coordinate the execution of organization activities, and hence to deliver services, but rely on ICTs to sustain procedural efficiency. ICTs are used in order to facilitate and support the fundamental organizational functions of coordination and control of bureaucratic organizations. These functions are defined in the legal-normative set of rules designed to standardize the administrative procedure and the delivery of public services. As mentioned in literature [33] eGovernment can be seen as the application of information and communication technologies in order to redesign ways in which governments exchange information with stakeholders but ICTs do not transform government by themselves. State structures, preexisting institutional structures, legal, regulatory and cultural factors determine how specific technological innovations look and how specific institutional change will take place.

When it comes to solving eGovernment problems the meaning of comparative legal research has to be underlined. To ensure success of eGovernment, more research is required to determine which exact solutions can be defined as guarantees of the right to good administration. As mentioned by V. Homburg [34], one way of exploring specific relations between characteristics of technology on the one hand and institutional, social, economic and political factors on the other hand, is to scrutinize and compare technologies in various settings, for example countries. Such studies could inform of what exact constellations of actors, interests, power bases and control potentials stimulate, mediate or obstruct technology in public administration. eGovernment is based on national and local sets of rules. The need exists for each country to understand and improve the effective and efficient use of eGovernment for information exchange at an international level [35]. J. T. Snead and E. Wright underline that more theory-based efforts are needed to understand eGovernment as a field of study.

\section{Relationship between eGovernment and right to good administration}

It is worth emphasizing that good administration standards, understood as a theoretical generalization of both principles and guidelines, are connected with good governance requirements $[36,37,38,39,40]$, or in general with the notion of democratic rule [41]. In particular, direct relationship occurs with such principles as: co-participation on equal rights, rule of law, transparency, punctuality, partnership and social dialogue (the consensus principle), fairness and share, efficiency and productivity, as well as responsibility [42]. Presently, good administration standards together with other constitutional norms restrict reforms undertaken in the country [43].

By way of illustration, in Poland the right to good administration has not been directly expressed in the national legal system. However, the good administration principle can be recognized as a legal principle stemming from the notion of the democratic rule of law, and also corresponding with other constitutional norms [44]. A similar situation is in other European countries, e.g. in Romania [45]. Right to good administration and principle of good administration have also been used in legal practice, e.g. regarding changes in the land and building register [46], in case of mutual information and cooperation between institutions [47], in the matter of occupying the road lane [48], in the scope of excessive length of proceedings regarding the tax on goods and services [49], regarding inactivity in the field of property expropriation [50].

Some Authors notice [51], that the right to good administration can be understood in a broader way and cover not only eGovernment but also eGovernance. That is because, as already mentioned, the right to good administration comprises in itself the right to good governance. In such understanding, the key elements of good governance comprise effective mechanisms for citizen participation, a transparent and corruption-free political system, accountability of public authorities, modern 
administrative services, inclusion of vulnerable groups and introduction of eGovernance. The transformation from eGovernment to eGovernance comes from the rise of eParticipation and is much more than just providing information and services. It is the usage of information and communication technologies at various levels of the public sector and beyond for the purpose of enhancing governance [52].

The core of the right to good administration resulting from the Charter of Fundamental Rights of the EU is for all affairs to be handled impartially, fairly and within a reasonable time. This condition can be met by using eGovernment solutions, e.g. by eliminating the human element and human's discretionary nature. Often, eGovernment solutions are perceived as tools to fight corruption or eliminate arbitrariness of decisions taken by public administration. In addition, reliability of administrative proceedings can be guaranteed by eGovernment solutions by way of ensuring that every procedure is clearly defined, and will follow strict principles, e.g. on the basis of the principle of providing information using continuous and current access to information and events taking place during administrative proceedings (e.g. access websites like www.borger.dk in Denmark). eGovernment can be considered from the point of view of time savings, but also knowledge about the starting time and closing time of administrative proceedings. Thanks to ICT solutions both the party involved and the supervisory authority can have information about the excessive length of the proceedings and inactivity of the administrative body.

Thus the question arises, whether all eGovernment solutions guarantee the right to good administration. In addition, whether this applies only to services characteristic for eAdministration, or more broadly, also services related to eDemocracy, eParticipation, or eVoting.

The authors of this paper hold the position that all properly interpreted eGovernment solutions guarantee the right to good administration. In their opinion, this applies not only to solutions characteristic for eAdministration, but also e.g. eDemocracy. The right to good administration does not merely apply to the affairs of an individual, with respect to public administration, handled by way of a decision, order or administrative arrangement [53], but in a broader meaning, it may also apply to different contacts between entities being subject to administration, with the administrative bodies themselves, which consists of different forms like questions, requests, protests, filing comments to draft legal regulations, or bills initiated by citizens. One must however underline that it is impossible to illustrate the link between the right to good administration and eGovernment issues on factual lawsuits or legal practice.

The aforementioned legal and comparative studies gain paramount importance from the point of view of the right to good administration. Legal and comparative studies should be continued in that respect, while an attempt to answer the question about relations between the right to good administration and eGovernment is becoming an important one in the context of administrative law.

\section{Summary}

Summarizing the above considerations, it should be pointed that although the issues of the right to good administration and eGovernment may seemingly be not connected, in fact the relationship between them is quite strong. This analysis shows that implementation of eGovernment projects may be financially justified in the light of the principles of good administration. Additionally, such projects fulfill the right to good administration. The three key pillars, namely impartiality, fairness and reasonable time of resolving affairs can be achieved in fact by eGovernment projects. Additionally, this applies not only to the narrowly understood eAdministration, but broadly 
considered eGovernment, and even eGovernanace or good governance. While there is a high number of studies and analyses focusing on each of these concepts separately, it is very rare, if at all, to find a study that would identify eGovernment as a guarantor of implementing the principle of good administration. Without any question, good administration requirements were connected with the concept of good governance.

The scope of this paper allowed the Authors to only highlight the fundamental issues related to the definition of the aforementioned concepts or methods of implementation, but at the same time allowed them to clearly express the conviction that they concepts interpenetrate one another. Furthermore, it should be reiterated that studies in this area should be continued and broadened, in particular legal-and-comparative studies, taking into account existing and planned solutions related to the right of good administration, eGovernment at European level, and at national levels in member state legal systems.

\section{References}

[1] LIPOWICZ, I., Prawo obywatela do dobrej administracji [A citizen's right to good administration], in: Hauser, R., Nowacki, J. (ed.), Państwo w służbie obywateli. Księga jubileuszowa Jerzego Świątkiewicza [The state in the service of citizens. Jerzy Świątkiewicz’s jubilee book], Łódź: "Master", Warsaw 2005, p. 130.

[2] SZPOR, A., Odwaga służenia dobru wspólnemu [Courage to serve the common good], in: Niewiadomski, Z., Cieślak, Z. (ed.), Prawo do dobrej administracji, Materiały ze Zjazdu Katedr Prawa i Postępowania Administracyjnego, Warszawa - Dębe 23-25 września 2002 [Right to good administration. Materials from the convent of Law and Administration Procedure Faculties Warszawa-Dębe 23-25 September 2002], Wydawnictwo Uniwersytetu Kardynała Stanisława Wyszyńskiego, Warsaw 2003, p. 640.

[3] The Charter of Fundamental Rights of the European Union proclaimed in Strasbourg on 12 December 2007 by the European Parliament, Council and Committee (Official Journal C 303 of 14 Dec. 2007, p. 1).

[4] Treaty of Lisbon amending the Treaty on European Union and the Treaty establishing the European Community signed in Lisbon on 13 December 2007 (EU Journal of Laws C 306 of 2007, p. 1).

[5] European Parliament resolution of 15 January 2013 with recommendations to the Commission on a Law of Administrative Procedure of the European Union, P7_TA(2013)0004, http://www.europarl.europa.eu/sides/getDoc.do?pubRef=-//EP//TEXT+TA+P7-TA-20130004+0+DOC+XML+V0//PL (10 Oct. 2013).

[6] SUPERNAT, J., Dobra administracja w prawie Unii Europejskiej [Good administration in European Union law], in: Sługocki, J. (ed.), Dziesięć lat polskich doświadczeń w Unii Europejskiej. Problemy prawnoadministracyjne [Ten years of Polish experiences in European Union. Legal and administrative problems], v. 1, PRESSCOM Sp. z o.o., Wrocław 2014, pp. 665-667.

[7] PRINC, M., Komentarz do Rezolucji Parlamentu Europejskiego z dnia 15 stycznia 2013 r. zawierającej zalecenia dla Komisji w sprawie prawodawstwa dotyczącego postępowania 
administracyjnego w Unii Europejskiej [Comments to the European Parliament resolution of 15 January 2013 with recommendations to the Commission on a Law of Administrative Procedure in the European Union], Studies in Public Law 4 (2013), pp. 175-188.

[8] CIEŚLAK, Z., Prawo do dobrej administracji (tezy wystąpienia) [Right to good administration (topics of the speech)], in: Niewiadomski, Z., Cieślak, Z. (ed.), Prawo do dobrej administracji, Materiały ze Zjazdu Katedr Prawa i Postępowania Administracyjnego, Warszawa - Dębe 23-25 września 2002 [Right to good administration. Materials from the convent of Law and Administration Procedure Faculties Warszawa-Dębe 23-25 September 2002], Wydawnictwo Uniwersytetu Kardynała Stanisława Wyszyńskiego, Warsaw 2003, p. 18.

[9] LIPOWICZ, I., O mądre prawo i wrażliwe państwo [For a wise law and sensitive country], Biuletyn Rzecznika Praw Obywatelskich 80 (2013), p. 67.

[10] BRODECKI, Z., Substrat - prawo [Substrate - the law] [in:] BRODECKI Z. (ed.), Europa urzędników [A Europe of officials], LexisNexis Polska, Warsaw 2009, p. 76.

[11] KMIECIAK, Z., Postępowanie administracyjne i sądowo administracyjne a prawo europejskie [Administrative and court-and-administrative procedure vs. European law], Wolters Kluwer Polska, Warsaw 2010, p. 60.

[12] BRODECKI, Z. (ed.), Europa urzędników [A Europe of officials], LexisNexis Polska, Warsaw 2009, p. 99.

[13] SZYDŁO, M., Prawo do dobrej administracji jako prawo podstawowe w unijnym porządku prawnym [The right to good administration as a fundamental right in EU legal system], Studia Europejskie 1 (2004), p. 87-107.

[14] MENDES, J., Good administration in EU Law and European Code of Good Administrative Behaviour, EUI Working Paper 9 (2009), p. 4.

[15] LIPOWICZ, I., O mądre prawo i wrażliwe państwo [For a wise law and sensitive country], Biuletyn Rzecznika Praw Obywatelskich 80 (2013), p. 65.

[16] DOBKOWSKI, J., Kodeks dobrej administracji Rady Europy (geneza - charakter - treści) [Code of good administration of the Council of Europe (origin - character - content)], in:

Niczyporuk, J., Kodyfikacja postępowania administracyjnego na 50 lecie K.P.A.

[Codification of the administrative procedure on the occasion of the 50th anniversary of the Code of Administrative Procedure],Wydawnictwo WSPA, Lublin 2010, p. 138.

[17] JACKIEWICZ, A. I., Prawo do dobrej administracji jako standard europejski [The right to good administration as a European standard], Wydawnictwo Adam Marszałek, Torun 2008.

[18] CHRÓŚCIELEWSKI, W., KMIECIAK, Z., Kodeks postępowania administracyjnego a prawo do dobrej administracji [Code of administrative procedure and the right to good administration], in: Niczyporuk, J., Kodyfikacja postępowania administracyjnego na 50 lecie K.P.A. [Codification of the administrative procedure on the occasion of the 50th anniversary of the Code of Administrative Procedure], Wydawnictwo WSPA, Lublin 2010, p. 68. 
[19] PRINC, M., Standardy dobrej administracji w prawie administracyjnym [Standards of good administration in administrative law], Wydawnictwo UAM, Poznań 2017, p. 113-114.

[20] TOMASZEWSKA, K., Dobre praktyki organów administracji publicznej w dostępie do geoinformacji w świetle ustawy o infrastrukturze informacji przestrzennej [Good practice of public administrative authorities in the access to geoinformation in the light of the Act on Infrastructure of Spatial Information], in: Gołaczyński, J. (ed.), Wybrane dobre praktyki w zakresie usług elektronicznych [Selected good practice regarding electronic services], C. H. Beck, Warsaw 2016, pp. 115-116.

[21] RAMON GIL-GARCIA, J., Enacting Electronic Government Success. An Integrative Study of Government-wide Websites, Organizational Capabilities, and Institutions, Springer, New York 2012, pp. 4-17.

[22] AL-HUJRAN, O., AL-DEBEI, M. M., CHATFIELD, A., MIGDADI, M., The imperative of influencing citizen attitude toward e-government adoption and use, Computers in Human Behavior 53 (2015), pp. 189-203.

[23] SUPERNAT, J., Administracja publiczna, governance i nowe publiczne zarządzanie [Public administration, governance and new public management], in: Blicharz, J., Boć, J. (ed.), Prawna działalność instytucji społeczeństwa obywatelskiego [Legal activity of civil society institutions], Kolonia Limited, Wrocław 2009, p. 139.

[24] FUGINI, M. G., MAGGIOLINI, P., VALLES, R. S., e-Government and Employment Services. A Case Study in Effectiveness, Springer, Cham 2014.

[25] RODRIGUEZ-BOLIVAR, M., P. (ed.), Measuring E-government Efficiency. The Opinions of Public Administrators and Other Stakeholders, Springer, New York 2014.

[26] BHATNAGAR, S., Unlocking E-Government Potential. Concepts, Cases and Practical Insights, SAGE Publications, New Delhi 2009, p. 32.

[27] ANTHOPOULOS, L., REDDICK, Ch. G., GIANNAKIDOU, I., MAVRIDIS, N., Why egovernment projects fail? An analysis of the Healthcare.gov website, Government Information Quarterly 33 (2016), pp. 161-173.

[28] DR PERRI 6, E-governance. Styles of Political Judgement in the Information Age Polity,Palgrave Macmillian, New York 2004, p. 16.

[29] DĄBROWSKA, A., JANOŚ-KRESŁO, M., WÓDKOWSKI, A., E-services and the information society [E - usługi a społeczeństwo informacyjne], Difin, Warsaw 2009, p. 48.

[30] HOMBURG, V., Understanding E-government: Information systems in public administration, Routledge, New York 2008, p. 57.

[31] FOUNTAIN, J. E., Toward a Theory of Federal Bureaucracy for the Twenty-First Century, in: Kamarck, E. C., Nye Jr., J. S. (ed.), Governance.com. Democracy in the Information Age, Booking Institutions Press, Washington 2002, pp. 118-119. 
[32] CORDELLA, A., TEMPINI, N., E-government and organizational change: Reappraising the role of ICT and bureaucracy in public service delivery, Government Information Quarterly 32 (2015), pp. 279-286.

[33] POLlitT, Ch., VAN THIEL, S., HOMBURG, V., New Public Management in Europe, Management Online Review, 10 (2007), pp. 1-7.

[34] HOMBURG, V., Understanding E-government: Information systems in public administration, Routledge, New York 2008, pp. 126-127.

[35] SNEAD, J. T., WRIGHT, E., E-government research in the United States, Government Information Quarterly 31 (2014), pp. 129-136.

[36] KRAWIEC,G., Europejskie prawo administracyjne [European administrative law], Wolters Kluwer Polska, Warsaw 2009, pp. 23-25.

[37] WAKEFIELD, J., The right to good administration, Kluwer Law International, The Hague 2007.

[38] STEFAŃSKA, E., Decyzje o odmowie przyznania własności czasowej nieruchomości w trybie dekretu warszawskiego jako przykład patologii w funkcjonowaniu administracji [Decisions on refusal to grant temporary ownership to real property under the Warsaw decree as an example of pathology in the operation of administration], in: Suwaj, P. J., Kijowski, D. R., Patologie w administracji publicznej [Pathologies in public administration], Wolters Kluwer Polska, Warsaw 2009, p. 356.

[39] IZDEBSKI, H., Zasada dobrej administracji i prawo do dobrej administracji w świetle standardów Rady Europy [The principle to good administration and the right to good administration in the light of the standards of the Council of Europe], in: Machieńska,H., 60 lat Rady Europy. Tworzenie i stosowanie standardów prawnych [60 years of the Council of Europe. Creation and application of legal standards], Wydawnictwo Wiedza i Praktyka, Warsaw 2009, p. 324.

[40] IZDEBSKI, H., Fundamenty współczesnych państw [Foundations of current states], Wydawnictwo Prawnicze LexisNexis, Warsaw 2007, p. 210 ff.

[41] OBAIDULLAH, A. T. M, Democracy and good governance. The role of ombudsman, Bangladesh Institute of Parliamentary Studies, Dhaka 2001, p. 1 ff.

[42] United Nations Economic Commission for Europe, Guidebook on promoting good governance in public-private partnerships, New York - Geneva 2008, p. 13.

[43] KARPEN, U., Good Governance, European Journal of Law Reform, No 12 (2010), p 22.

[44] PRINC, M., Standardy dobrej administracji w prawie administracyjnym [Standards of good administration in administrative law], Wydawnictwo UAM, Poznań 2016, p. 17. 
[45] APOSTOLACHE, M., Ch., The Constitutionalization of the Right to Good Administration and the Implications on Local Public Administration, Analele Universitatii Titu Maiorescu, Seria Drept, (2015) - Anul XIV, p. 28.

[46] The Voivodship Administrative Court in Gdańsk in the resolution of 5 May 2016, Case No. III SA/Gd 703/15.

[47] The Voivodship Administrative Court in Gorzów Wielkopolski in the resolution of 16 September 2008, Case No. II SA/Go 358/08.

[48] The Voivodship Administrative Court in Szczecin in the resolution of 16 November 2005, Case No. II SA/Sz 705/05.

[49] The Supreme Administrative Court in the resolution of 14 December 2017, Case No. I FSK $102 / 16$.

[50] The Voivodship Administrative Court in Warsaw in the resolution of 13 December 2017, Case No. IV SAB/Wa 210/17.

[51] CHESHMEDZHIEVA, M., The Right to Good Administration, American International Journal of Contemporary Research, Vol. 4, No. 8 (2014), pp. 64-67.

[52] HOLZER, M., ZHENG, Y., Best Practices in E-Governance: A Comparative Study Based on the Rutgers University Worldwide Digital Governance Survey, in: Reddick, Ch. G., Anthopoulos L. (ed.), Information and Communication Technologies in Public Administration. Innovations from Developed Countries, CRC Press, Boca Raton 2015, p. 32.

[53] SUPERNAT, J., Zasady dobrej administracji [Principles of good administration], in: Niewiadomski, Z., Cieślak, Z., (ed.) Prawo do dobrej administracji, Materiały ze Zjazdu Katedr Prawa i Postępowania Administracyjnego, Warszawa-Dębe 23-25 września 2002 [Right to good administration. Materials from the convent of Law and Administration Procedure Faculties Warszawa-Dębe 23-25 September 2002], Wydawnictwo Uniwersytetu Kardynała Stanisława Wyszyńskiego, Warsaw 2003, p. 598-615. 